\title{
Tracking stem cells with superparamagnetic iron oxide nanoparticles: perspectives and considerations
}

This article was published in the following Dove Press journal:

International Journal of Nanomedicine

25 January 2017

Number of times this article has been viewed

Jasmin ${ }^{1, *}$

Gustavo Torres de Souza ${ }^{2,3, *}$

Ruy Andrade Louzada ${ }^{4}$

Paulo Henrique Rosado-de-

Castro $^{5}$

Rosalia Mendez-Otero ${ }^{6}$

Antonio Carlos Campos de Carvalho ${ }^{6}$

'NUMPEX-Bio, Federal University of Rio de Janeiro, Duque de Caxias, RJ, 'Laboratory of Animal Reproduction, Embrapa Dairy Cattle, Juiz de Fora, MG, ${ }^{3}$ Laboratory of Genetics, Federal University of Juiz de Fora, Juiz de Fora, MG, Brazil; ${ }^{4}$ Institute GustaveRoussy of Oncology, Paris-Sud University, Villejuif, France; ${ }^{5}$ Institute of Biomedical Sciences, Federal University of Rio de Janeiro, Rio de Janeiro, RJ, ${ }^{6}$ Institute Carlos Chagas Filho of Biophysics, Federal University of Rio de Janeiro, Rio de Janeiro, RJ, Brazil

*These authors contributed equally to this work
Correspondence: Jasmin Estrada de Xerém, 27, NUMPEXBio - UFRJ, Xerém, Duque de Caxias, RJ, 25245-390, Brazil

Tel +55 2I 2679 I0I8

Email jasmin@biof.ufrj.br
Abstract: Superparamagnetic iron oxide nanoparticles (SPIONs) have been used for diagnoses in biomedical applications, due to their unique properties and their apparent safety for humans. In general, SPIONs do not seem to produce cell damage, although their long-term in vivo effects continue to be investigated. The possibility of efficiently labeling cells with these magnetic nanoparticles has stimulated their use to noninvasively track cells by magnetic resonance imaging after transplantation. SPIONs are attracting increasing attention and are one of the preferred methods for cell labeling and tracking in preclinical and clinical studies. For clinical protocol approval of magnetic-labeled cell tracking, it is essential to expand our knowledge of the time course of SPIONs after cell incorporation and transplantation. This review focuses on the recent advances in tracking SPION-labeled stem cells, analyzing the possibilities and limitations of their use, not only focusing on myocardial infarction but also discussing other models.

Keywords: nanoparticles, superparamagnetic iron oxide nanoparticles, stem cells, cell tracking, in vivo imaging, myocardial infarction

\section{Introduction}

Stem cells have emerged as a novel therapeutic option for cell death-related diseases, such as myocardial infarction. The effects of adult stem cells on damaged tissues are currently attributed mainly to proliferation, inhibition of apoptosis and inflammation, and increase in angiogenesis caused by the secretion of paracrine factors by injected stem cells, thus stimulating tissue regeneration and repair. ${ }^{1-4}$ However, the difficulty of evaluating and determining the precise contribution of each mechanism involved in cell-based treatments is one of the obstacles to their approval for clinical use. ${ }^{5,6}$ Methods to determine the biodistribution and fate of injected cells are required to understand and refine stem cell therapies in patients.

The outcomes of clinical trials using stem cells are less assessable by invasive methods, which are usually used in experiments with animal models and include postmortem analyses, such as histologic analysis of tissues and organs. ${ }^{78}$ Currently, there are active efforts to develop and standardize suitable noninvasive methods for long-term tracking of cells after transplantation. ${ }^{9}$

Magnetic resonance imaging (MRI) offers an imaging modality that allows highresolution visualization of cell biodistribution. ${ }^{10-14}$ Several types of contrast agents have been used for MRI in vivo imaging, including superparamagnetic iron oxide nanoparticles (SPIONs), which successfully label different mammalian cell types. ${ }^{15-19}$ 
In this review, we discuss the main characteristics and limitations of molecular imaging technologies to investigate cellular biodistribution and fate. The primary focus was on SPION labeling methods for stem cells tracking in a myocardial infarction model, but we also discussed other models, markers, and molecular imaging techniques. We have reviewed the literature in the field and also provided unpublished data on mesenchymal stem cells labeling and tracking in the myocardial infarction model.

For this review, we consulted relevant articles published on prominent journals for each specific area covered in the topics, provided that they were indexed on PubMed, Wiley's Library, Science Central, and/or Google Scholar. We used the following keywords for our search: SPIONs, nanoparticles for cell labeling, cell tracking, tracking cells in myocardial infarction, in vivo cellular imaging, MRI, molecular imaging technologies, and nanoparticles toxicity.

\section{Labeling stem cells and molecular imaging methods}

Two main approaches are used to label cells for in vivo tracking: direct and indirect labeling. Direct labeling involves a relatively simple step of in vitro incorporation of the marker molecule before the cell therapy. ${ }^{20} \mathrm{~A}$ range of molecules can be used, and this technology is considered fairly well established and yields consistent and reproducible results. SPIONs, fluorescent dyes, or radionuclides can be used as probes to directly prelabel stem cells for noninvasive tracking. ${ }^{9,21-23}$ Standardized protocols used for labeling stem cells with SPIONs were previously compiled by us, ${ }^{15,24}$ and other direct-labeling reagents were reviewed by Marks and Nolan ${ }^{25}$ and Progatzky et al. ${ }^{26}$

Indirect labeling is a considerably different method, which includes genetic modification in order to either produce an appropriate signal-generating molecule or increase the affinity of cells to contrast agents. , $^{91,27-32}$ Transient expression of reporter proteins by DNA vector transfection is often included in this set of cell labeling. ${ }^{9}$ Another alternative is stable expression of the reporter protein by transduction of the cells with a virus. Differently from transient expression, stably transformed cells will continue to produce the protein of interest for long periods and allow us to monitor not only its biodistribution and cell fate but also cell proliferation, considering that the daughter cells will also produce the marker. ${ }^{21,32}$

Indirect and direct methods might serve the purpose of successfully labeling stem cells for noninvasive tracking in vivo. Table 1 summarizes the advantages and disadvantages of each method. ${ }^{9}$
Table I Favorable and unfavorable features of direct and indirect cell tracking methods

\begin{tabular}{|c|c|}
\hline Direct labeling & Indirect labeling \\
\hline Relatively easy technique & Requires specialized technical skills \\
\hline $\begin{array}{l}\text { Usually involves ex vivo } \\
\text { cell culture }\end{array}$ & Involves ex vivo cell culture \\
\hline $\begin{array}{l}\text { No genetic } \\
\text { manipulation needed }\end{array}$ & Requires expertise in molecular biology \\
\hline Less expensive & More expensive \\
\hline $\begin{array}{l}\text { Reduced risk of } \\
\text { manipulation }\end{array}$ & $\begin{array}{l}\text { Biosafety concerns about manipulation } \\
\text { of retro- or lentiviral vectors and } \\
\text { disposal of materials }\end{array}$ \\
\hline $\begin{array}{l}\text { No direct risk of } \\
\text { mutagenesis }\end{array}$ & $\begin{array}{l}\text { Risk of mutagenesis in the } \\
\text { transformed cells }{ }^{132}\end{array}$ \\
\hline Signal fades with time & $\begin{array}{l}\text { Signal is maintained for long periods in } \\
\text { stable transformation (excluding the } \\
\text { possibility of gene silencing) }\end{array}$ \\
\hline $\begin{array}{l}\text { The marker is diluted in } \\
\text { daughter cells }\end{array}$ & $\begin{array}{l}\text { The marker continues to be produced by } \\
\text { daughter cells (in stable transformation) }\end{array}$ \\
\hline $\begin{array}{l}\text { Provides no information } \\
\text { about in vivo cell } \\
\text { proliferation }\end{array}$ & $\begin{array}{l}\text { Allows assessment of cell proliferation } \\
\text { (in stable transformation) }\end{array}$ \\
\hline $\begin{array}{l}\text { Marker might be diffused } \\
\text { to host tissue and host } \\
\text { non-target cells }\end{array}$ & $\begin{array}{l}\text { Signal generated only in the initially } \\
\text { prepared cells }\end{array}$ \\
\hline $\begin{array}{l}\text { Easily translatable to } \\
\text { human uses }\end{array}$ & Mostly not applicable to human uses \\
\hline
\end{tabular}

The term "molecular imaging" can be broadly defined as the in vivo characterization and measurement of biological processes at the cellular and molecular levels. ${ }^{33}$ Here, for our purposes, molecular imaging methodologies are related to the observation of specific cell markers present in the injected cells, in order to follow their biodistribution in a time-dependent manner with noninvasive methods.

The different cell markers available can be monitored in vivo by various imaging methods. The most commonly used methods are summarized in Table 2 and have been thoroughly reviewed in studies by Kircher et al, ${ }^{9}$ Hong et al, ${ }^{21}$ Naumova et al, ${ }^{22}$ James and Gambhir, ${ }^{34}$ Chen et al, ${ }^{35}$ and Zhang et al. ${ }^{36}$

For preclinical or clinical studies, it is essential to consider the advantages and disadvantages of each molecular imaging modality. The challenge is to develop effective imaging strategies with a combination of imaging modalities, labeling reporter systems, and probes.

\section{Properties of SPIONs}

Although several studies have used SPIONs for health-related purposes, their intrinsic properties have been little discussed. In this section, we provide an overview of the main characteristics and techniques involved in the production of SPIONs and discuss possible concerns regarding their use. 
Table 2 Molecular imaging methods applied in cell tracking

\begin{tabular}{|c|c|c|c|}
\hline $\begin{array}{l}\text { Molecular } \\
\text { imaging }\end{array}$ & Principle of functioning & Suitable cell labels & Comments \\
\hline PET & $\begin{array}{l}\text { Detection and tracking of gamma-ray } \\
\text { photons generated by the annihilation } \\
\text { between positrons }\end{array}$ & $\begin{array}{l}\text { Radionuclides such as }{ }^{11} \mathrm{C} \text {, } \\
{ }^{33} \mathrm{~N},{ }^{15} \mathrm{O},{ }^{18} \mathrm{~F},{ }^{64} \mathrm{Cu},{ }^{76} \mathrm{Br} \text {, } \\
\text { labeled molecules containing } \\
\text { radionuclides (eg, }\left[{ }^{18} \mathrm{~F}\right] \text {-2-fluoro- } \\
\text { 2-deoxy-glucose) }\end{array}$ & $\begin{array}{l}\text { Suitable for clinical applications } \\
\text { High sensitivity and low spatial } \\
\text { resolution } \\
\text { Radionuclides have a short half- } \\
\text { life and emit ionizing radiation }\end{array}$ \\
\hline SPECT & $\begin{array}{l}\text { Detection and tracking of single } \\
\text { gamma-ray photons }\end{array}$ & $\begin{array}{l}{ }^{99 \mathrm{~m} T c,}{ }^{123} \mathrm{I},{ }^{\prime \prime ' I n, ~ n u c l i d e-~} \\
\text { labeled molecules (eg, ["'In] } \\
\text { oxyquinoline (oxine) or [99mTc]- } \\
\text { hexamethylpropyleneamine- } \\
\text { oxine) }\end{array}$ & $\begin{array}{l}\text { Suitable for clinical applications } \\
\text { High sensitivity and low spatial } \\
\text { resolution } \\
\text { Radionuclides have a short half- } \\
\text { life and emit ionizing radiation }\end{array}$ \\
\hline $\begin{array}{l}\text { Magnetic } \\
\text { resonance } \\
\text { imaging }\end{array}$ & $\begin{array}{l}\text { Alignment of the proton spins in the } \\
\text { tissues with the magnetic field of the } \\
\text { scan, generating a signal }\end{array}$ & SPIONs, gadolinium complexes & $\begin{array}{l}\text { Suitable for clinical applications } \\
\text { High spatial resolution and } \\
\text { detection of functional data } \\
\text { Less sensitive than PET/SPECT }\end{array}$ \\
\hline $\begin{array}{l}\text { Fluorescence } \\
\text { imaging }\end{array}$ & $\begin{array}{l}\text { Detection of the photons emitted from } \\
\text { a fluorescent agent previously excited } \\
\text { by light with a selected wavelength, by } \\
\text { using a charge-coupled device camera }\end{array}$ & $\begin{array}{l}\text { Fluorescent proteins (eg, green } \\
\text { fluorescent protein), fluorescent } \\
\text { dyes (eg, alexafluor, rhodamine), } \\
\text { antibodies conjugated with } \\
\text { fluorescent dyes }\end{array}$ & $\begin{array}{l}\text { Not yet clinically translatable } \\
\text { High sensitivity } \\
\text { Limited penetration depth and } \\
\text { poor spatial resolution }\end{array}$ \\
\hline $\begin{array}{l}\text { Bioluminescence } \\
\text { imaging }\end{array}$ & $\begin{array}{l}\text { Detection of the photons emitted } \\
\text { during enzymatic oxidation reactions in } \\
\text { the labeled cells }\end{array}$ & Luciferase/luciferin & $\begin{array}{l}\text { Not yet clinically translatable } \\
\text { High sensitivity } \\
\text { Limited penetration depth and } \\
\text { poor spatial resolution }\end{array}$ \\
\hline
\end{tabular}

Abbreviations: PET, positron emission tomography; SPECT, single photon emission computed tomography; SPIONs, superparamagnetic iron oxide nanoparticles.

The first iron oxide nanoparticles were developed in 1995. These were dextran-coated iron oxide nanoparticles with a $100-150 \mathrm{~nm}$ hydrodynamic radius and contained a $5-10 \mathrm{~nm}$ iron oxide core. ${ }^{37}$ Notably, gadolinium, a paramagnetic metal ion extensively used to enhance contrast in MRI, can also be used for direct labeling and tracking of cells. Different formulations of gadolinium and SPIONs were clinically approved for in vivo diagnostics.

The functioning core of SPIONs is composed of nanostructured iron oxide molecules, of which the most commonly used are $\mathrm{Fe}_{3} \mathrm{O}_{4}$ (magnetite), $\gamma-\mathrm{Fe}_{2} \mathrm{O}_{3}$ (maghemite), and $\alpha-\mathrm{Fe}_{2} \mathrm{O}_{3}$ (hematite). ${ }^{38}$ Both the chemical composition and the nanostructure of the material are responsible for the characteristics exploited for several applications in biological sciences, such as superparamagnetism. ${ }^{39,40}$ Biocompatible SPIONs, such as magnetite, have been widely used for in vivo biomedical applications. Their slower renal clearance and higher relaxation values compared with the gadolinium-based contrast agents make them more attractive for imaging purposes. ${ }^{41}$ In 1949, Néel $^{42}$ first began to theorize about the magnetic behavior of singledomain particles, which are essentially nanoparticles displaying a single magnetic field direction. Superparamagnetism is a state in which the whole particle behaves as a paramagnetic atom, for example, the magnetic moment of this single-domain particle becomes aligned with the external magnetic field. ${ }^{42,43}$ For this reason, MRI is generally the technique of choice to observe SPIONs. MRI offers high resolution; simultaneous detection of functional, molecular, and anatomical data; and direct clinical translation. However, the sensitivity of MRI and its compatibility with many devices currently used in clinical practice still need to be improved. ${ }^{36}$

A precise nanostructure is fundamental to obtain reproducible and functioning magnetic nanoparticles. Therefore, the iron oxide molecules used to manufacture SPIONs occur naturally in the earth's crust, for research and clinical applications they must be synthesized under specific conditions in order to yield compounds of high purity and the appropriate size. ${ }^{41}$ Kaiser and Miskolczy ${ }^{44}$ were the first to report the synthesis of ferrofluidic magnetic colloids. Subsequently, other research groups reported the production of other compounds, although these compounds were not intended for biomedical applications. ${ }^{45-47}$

Relatively less expensive methods for producing nanoparticles of suitable quality must be explored for use in medical applications. ${ }^{48}$ SPIONs can be produced by physical, biological, or chemical methods, and this last is most often used. ${ }^{41}$ The precipitation of SPIONs from a solution is the preferred method, and results in the production of nanoparticles with relatively high quality and lower cost. ${ }^{41,47,49}$ Sen et al ${ }^{50}$ compared the early coprecipitation methods and suggested that the initial procedures published by Massart ${ }^{45}$ could result in spherical, uniformly sized particles. 
The biomedical and biological applications of SPIONs require them to be stable in water at neutral $\mathrm{pH}$ and physiological salinity. This colloidal stability depends on the dimensions of the particles, which must be sufficiently small to prevent them from precipitating due to gravitational force. Another important factor is the surface properties of SPIONs. Usually SPIONs are coated with a biocompatible polymer during or after the synthesis process in order to prevent the formation of large aggregates, changes from the original structure, and biodegradation when exposed to the biological system. In addition, a polymer coating can also allow binding of drugs or receptors/ligands, which will facilitate targeting to specific tissues or cells. These surface modifications of the SPIONs may be carried out during or after synthesis. ${ }^{41}$ For in vivo molecular imaging, the following coatings have been applied: polyethylene glycol, polyvinyl alcohol, dextran, starch, and liposomes. ${ }^{15,51-55}$

\section{Labeling of cells with SPIONs}

For the purposes of stem cell therapy, the inherent biological features of the cells are essential to attain the desired results. Thus, upon reaching the target, the cells are expected to be viable and proliferate appropriately, and not induce apoptosis or necrosis or undergo malignant transformation. Therefore, ideally, cell labels must not interfere with any of these properties. As additional requirements, the markers ought to be efficiently incorporated by the cells and their signal should not fade within a short time. ${ }^{9,21}$

Different SPIONs were approved for clinical application, tested in clinical trials, and commercially available for some time. For instance, the SPIONs Feridex/Endorem (dextrancoated, $120-180 \mathrm{~nm}$ in diameter) and Combidex/Sinerem (dextran-coated, 15-30 nm) were available from AMAG Pharmaceuticals/Guerbet, although both of them were eventually discontinued. The SPIONs Resovist (carboxydextrancoated, $60 \mathrm{~nm}$ ) and Supravist (carboxydextran-coated, $21 \mathrm{~nm}$ ) were produced by Bayer Schering Pharma AG,${ }^{56}$ and Resovist has been discontinued. GE Healthcare produced a SPION, Clariscan, coated with pegylated starch and $20 \mathrm{~nm}$ in diameter, which was also discontinued due to safety concerns. ${ }^{57}$

SPIONs were initially designed as contrast agents and were used primarily for diagnosis. The utilization of these same SPIONs for cell tracking is novel, but this labeling method has been severely affected by the discontinuation of commercially available SPIONs that were already approved for human use as contrast agents. Consequently, a number of preclinical studies have been published using SPIONs that are no longer commercially available or not yet approved for use in humans. This situation presents a clear opportunity for the development of new SPIONs suitable for clinical applications, now focusing on cellular tracking.

More recently, ferumoxytol (Feraheme $^{\circledR}$, AMAG Pharmaceuticals), an ultrasmall SPION that was originally approved by the US Food and Drug Administration as an iron supplement for treating iron deficiency in patients with chronic kidney disease ${ }^{58}$ has also been used for cell labeling. Castaneda et $\mathrm{al}^{59}$ described a protocol for using ferumoxytol and protamine to label human mesenchymal stem cells, human embryonic kidney 293 cells, and induced pluripotent stem cells. Skelton et al also used ferumoxytol to label cardiac progenitor cells derived from human embryonic stem cells. In this study, ferumoxytol was added at different time points and concentrations, and the authors reported that the concentration of $300 \mathrm{mg} / \mathrm{mL}$ on day 0 of cardiac differentiation provided the best results in terms of cell viability and signal intensity for MRI. The cells were transplanted intramyocardially, and labeled cells could be effectively imaged and tracked by MRI for up to 40 days. ${ }^{60}$

Besides those produced for clinical applications, several chemical companies also supply nonclinically approved SPIONs with different size ranges, coatings, and surface functionalities, as recently reviewed by Wang et al..$^{56}$

Our group has also used a nonclinically approved nanoparticle, FeraTrack (Miltenyi Biotec), to label and track bone marrow-derived mononuclear cells ${ }^{61,62}$ and mesenchymal stem cells $\mathrm{s}^{63}$ in different preclinical models of neurologic diseases. We were able to track labeled mononuclear cells after intravitreal injection in a rat model of optic-nerve crush, but 14 days post injection the signal derived from the transplanted cells was almost absent. ${ }^{61}$ Also using SPIONlabeled mononuclear cells, it was possible to observe labeled cells in a mouse model of amyotrophic lateral sclerosis after an injection into the spinal cord, even after 72 days post injection. However, using the antibody anti-Iba1 to identify microglia/macrophages in histologic sections, the authors observed many SPION-labeled cells in close apposition to Iba1-positive cells. It could be argued that part of the SPIONlabeled cells was phagocytized by resident microglia. ${ }^{62}$

In another study using MRI, we detected labeled mesenchymal stem cells for up to 18 weeks after intravitreal transplantation in a rat model of optic-nerve crush. Immunostaining with the antibody anti-Ibal revealed that the vast majority of the cells found in the vitreous body were negative for Iba1. ${ }^{63}$

Recently, Ngen et al proposed and validated a method of dual-contrast with SPIONs and gadolinium chelate. 
This technique successfully allowed them to assess both cell localization and cell death by MRI, as it is based on diffusional differences between a T2/T2* and a T1 contrast agent. The authors suggested that this technique could be used to evaluate cell-based therapies, by providing timely feedback about cell distribution and when cell death occurs after transplantation. ${ }^{64}$

One of the challenges in this field is to incorporate the SPIONs into the cells, as most stem cells are nonphagocytic. The incorporation of SPIONs by nonphagocytic cells can be facilitated by cationic compounds such as poly-L-lysine and protamine, due to their interaction with the negatively charged cell surface and subsequent endosomal uptake. ${ }^{15}$ Other incorporation facilitators are FuGENE, ${ }^{65}$ Superfect, and Lipofectamine. ${ }^{66}$ Among these facilitator agents, protamine has been widely used because it is already clinically approved for other purposes. ${ }^{67}$ The major advantage of these incorporation protocols is their simplicity, but they require an incubation period, and the necessity to culture the cells can be inconvenient. Magnetoelectroporation and magnetosonoporation induce reversible electromechanical permeability changes in cell membranes, facilitating rapid incorporation of the nanoparticles into freshly isolated cells. ${ }^{68,69}$ Similarly, Lei et al ${ }^{70}$ recently published an alternative method using focused ultrasound. However, the longterm effect of these procedures on the stem cell biology requires more thorough evaluation.

Several investigators, including our group, have reported a labeling procedure using a cationic compound to facilitate incorporation; this method is highly efficient, reaching virtually $100 \%$ of the cells. ${ }^{15,71-73}$ The data and images shown in Figure 1 illustrate the high proportion of bone marrowderived mesenchymal stem cells labeled with SPIONs.
For this experiment we used the SPION Feridex (AMAG Pharmaceuticals, Waltham, MA, USA) and protamine (Valeant Pharmaceuticals International, São Paulo, SP, Brazil) as a facilitator agent. Because Feridex is a dextrancoated nanoparticle, it can be quantified by fluorescence microscopy using an anti-dextran antibody.

Modifications of the SPION surface have been developed by different investigators (reviewed in the study by Bull et $\mathrm{al}^{74}$ ). Lee et $\mathrm{al}^{75}$ produced heparin-coated SPIONs and observed long-term cellular tracking of mesenchymal stem cells, increasing the utility of the technique. Barrow et al $^{76}$ synthesized dextran polymers with different surface charges, allowing enhanced SPION incorporation without the aid of facilitating agents.

In addition to the stem cell tracking, SPIONs have also been used to magnetically target stem cells to lesion sites, as described by Nishida et al. ${ }^{77}$ Hamasaki et al, ${ }^{78}$ successfully showed, in organotypic cultures, the possibility of enhancing axon formation by magnetically localizing SPION-labeled cells. Studies on the use of SPIONs to focus the delivery of stem cells to specific areas are still being conducted, and have been published by Cheng et $\mathrm{al}^{79}$ and by Ito et $\mathrm{al}^{80}$ as reviewed by Cores et al. ${ }^{81}$

\section{Potential toxicity}

Safety is a main concern, due to the unique and unusual properties acquired by compounds forming particles with nanometric sizes. Although SPIONs are currently the only metal oxide approved for medical uses, ${ }^{80,82}$ their potential toxicity is still under discussion.

Several toxicity parameters have been assessed, considering a possible negative effect on the physiology of labeled cells, even though long-term effects in humans have not
A

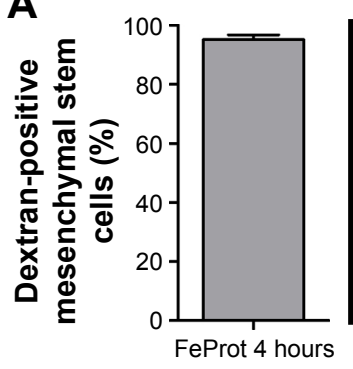

B
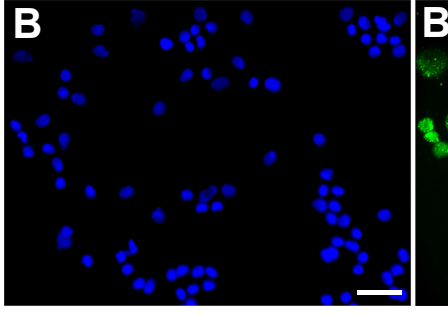
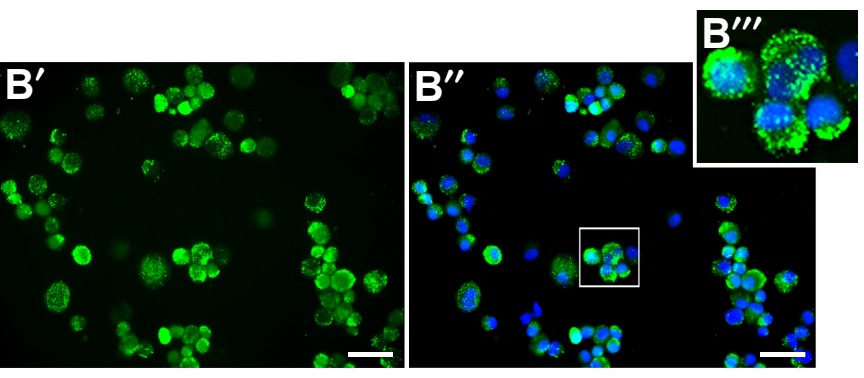

Figure I Mesenchymal stem cells incubated with superparamagnetic iron oxide nanoparticles.

Notes: Mesenchymal cells were harvested from bone marrow of Wistar rats and cultured for three passages. They were then incubated with Feridex $(50 \mu g / \mathrm{mL})$ and protamine $(5.0 \mu \mathrm{g} / \mathrm{mL})$ for 4 hours and trypsinized for subsequent transplantation. Immunostaining using the primary antibody anti-dextran (I:I000; Stem Cell Technologies, Vancouver, BC, Canada) was performed in trypsinized cells to detect the superparamagnetic iron oxide nanoparticles. (A) Graph showing the high proportion of dextranpositive cells. (B-B'") Fluorescent microscopy images, showing (B) nuclei stained with 4',6-diamidino-2-phenylindole (blue), (B') dextran-positive cells, and (B"') merged images. $\left(\mathbf{B}^{\prime \prime \prime}\right)$ Higher-magnification image of the area indicated by the white box. Scale bar $=50 \mu \mathrm{m}$. 
been reported. Relatively low toxicity has been found even when nanoparticle concentrations as high as $100 \mu \mathrm{g} / \mathrm{mL}$ were used, yet some studies have reported some level of damage to cells. ${ }^{82,83}$ Basically, in vitro experiments have demonstrated the toxicity of SPIONs, causing cellular stress, ${ }^{84-88}$ alterations in gene expression due to chromatin changes and genotoxicity, ${ }^{82,89,90}$ decrease in cell proliferation, ${ }^{83,85,87,88}$ and promotion of a proinflammatory environment. ${ }^{91-93}$

In most studies, SPIONs do not exert any reported effects on adipogenic ${ }^{94,95}$ and neurogenic differentiation. ${ }^{96}$ Divergent results have been obtained concerning osteogenic and chondrogenic differentiation. ${ }^{94-97}$ We were able to obtain chondrogenic, osteogenic, and adipogenic differentiation of mesenchymal stem cells after SPION labeling. ${ }^{15}$ More recently, Balakumaran et a ${ }^{98}$ successfully demonstrated the potential of SPION-labeled stem cells to appropriately differentiate in vivo.

Figure 2 shows Feridex-labeled mesenchymal stem cells harvested from bone marrow of Wistar rats, which are differentiated into adipocytes and chondrocytes. The SPIONs were present in the cells even after the differentiation process. Besides the possible toxicity directly related to the incorporation of SPIONs into the cytoplasm, it is important to point out the effects caused by the facilitating agent used and emphasizing the necessity of selecting suitable agents. We demonstrated this issue in a study where we used two types of facilitating agents, such as protamine and poly-Llysine. We showed that Feridex efficiently labeled mesenchymal stem cells when incubated with both agents for 4 or 24 hours. However, the complexes formed by Feridex and poly-L-lysine altered cell proliferation after 24 hours of exposure, a problem that was not observed with Feridex and protamine complexes. In addition, the protocol using Feridex with protamine did not affect cell viability for up to 7 days after incorporation and the in vitro differentiation potential, ${ }^{15}$ as shown in Figure 2. It has been suggested that poly-L-lysine can form large aggregates with SPIONs, which
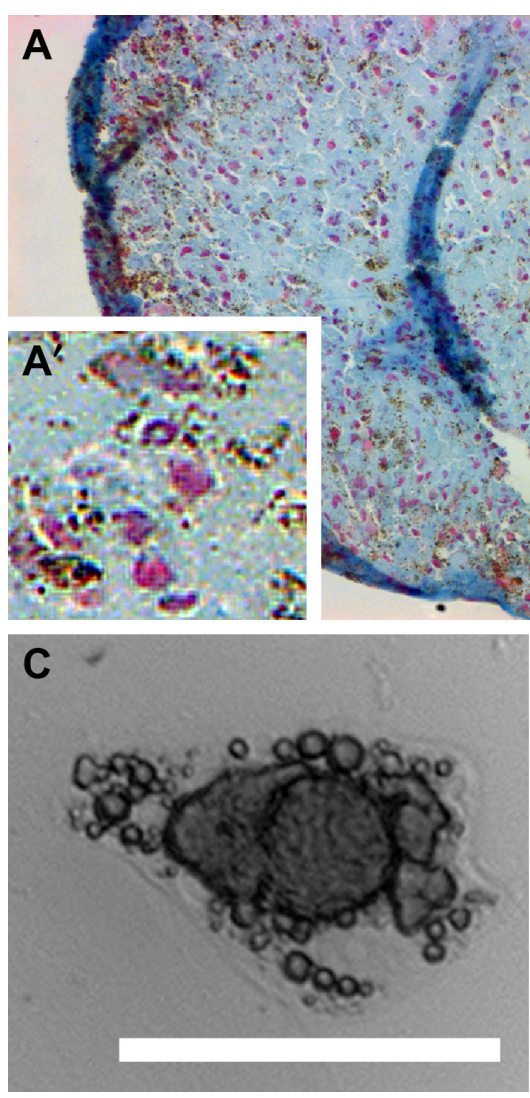
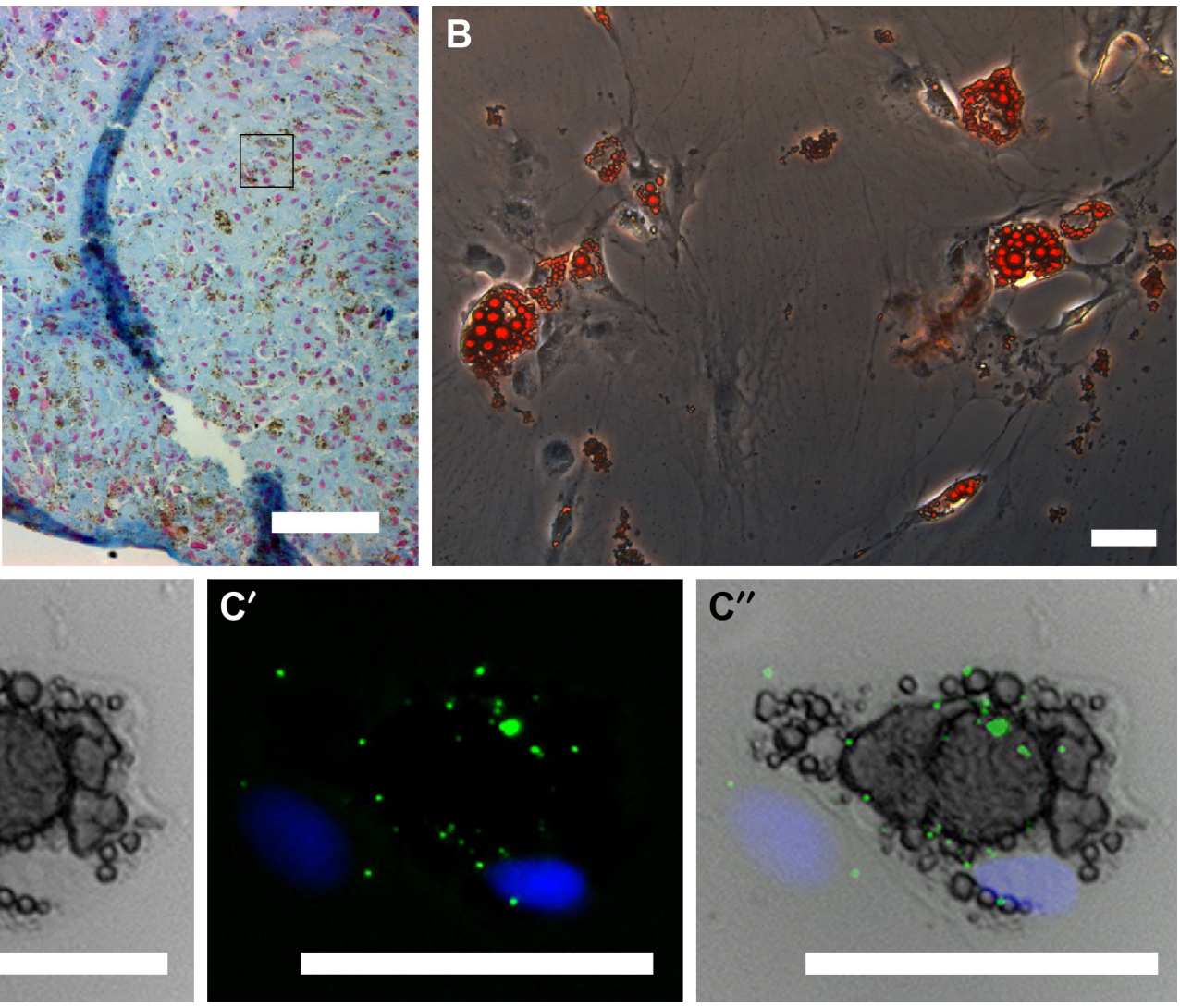

Figure 2 Differentiation potential of mesenchymal stem cells labeled with SPIONs.

Notes: Mesenchymal cells were harvested from bone marrow of Wistar rats, cultured, and induced to differentiate in chondrocytes and adipocytes after the exposure to Feridex $(50 \mu \mathrm{g} / \mathrm{mL})$ and protamine $(5.0 \mu \mathrm{g} / \mathrm{mL})$ for 4 hours. (A) Alcian blue staining showing chondrogenesis in Feridex-labeled cells. The nuclei were counterstained with nuclear fast red. (A') Higher magnification of the black box, showing brown deposits indicating the presence of SPIONs. (B) Oil Red $O$ staining indicating adipogenesis in labeled cells. (C-C') Representative images showing higher magnification of dextran-positive cells after adipocyte differentiation. These images were acquired in a black/white charge-coupled device camera, and thus red color from Oil Red staining is not visible in the figure. (C) Bright-field microscopy image of an adipocyte revealed by Oil Red

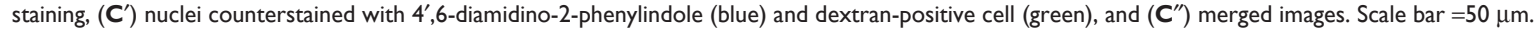

Abbreviation: SPION, superparamagnetic iron oxide nanoparticle. 
are not incorporated by the cells and remain attached to the plasma membrane, even in low concentrations. ${ }^{95}$

The toxicologic aspects of the nanoparticles deserve attention in experimental and clinical applications, but the toxicity results described in this section may have little impact on the general health of a patient after cell transplantation. ${ }^{82,83,99}$ However, the effects on the properties of cells to be utilized in therapies must be carefully investigated. Due to these concerns, it would be advisable to label only a small percentage of the injected cells in order to minimize the risks and maintain the therapeutic potential. For this reason, studies are needed to establish the minimal number of cells which will give a sufficient signal for cell tracking.

\section{Tracking cells in cardiovascular disease \\ Myocardial infarction}

Myocardial infarction may result from coronary artery disease, either as a first manifestation or in patients presenting the established disease. ${ }^{100}$ Diagnosis is based on clinical examination, electrocardiography, and the presence of specific cardiac biomarkers in the blood, such as cardiac troponin and creatine kinase-MB. ${ }^{101}$ The immense burden of cardiovascular diseases emphasizes the need for more research on ways to mitigate the deleterious effects of myocardial infarction. ${ }^{102}$

In addition to the biomarkers released in the blood during heart injuries, several growth factors related to regeneration, angiogenesis, and necrosis are also released. ${ }^{103}$ Ogawa et al ${ }^{103}$ recently reported the augmentation of vascular endothelial growth factor in patients with acute myocardial infarction. In the same year, the regulatory role of this cell factor was studied by Zhao et al. ${ }^{104}$ Two other ligands, nerve growth factor and myeloid-derived growth factor, have increased circulation levels after myocardial infarction and have been connected to postinjury myocardial regeneration. ${ }^{105,106}$ Similar to other striated muscles, the injured cell milieu generated by the damage dictates the tropism of resident progenitor and stem cells to the injury site, mediating a certain degree of self-recovery, ${ }^{103-107}$ but since the adult cardiomyocytes are known to be in mitotic arrest, this limits the repair mechanism. ${ }^{108,109}$

Thus, considering the low regeneration potential of the endogenous mechanisms attempts to stimulate regeneration by using exogenous stem cells seem plausible. ${ }^{110,111}$ Stem cell therapy has been reported to have beneficial effects in patients who had previously suffered a myocardial infarction. This issue, although controversial and not the focus of the present review, has been recently reviewed by Fisher et $\mathrm{al}^{111}$ and Wang et al. ${ }^{112}$

\section{Stem cell tracking in myocardial injury}

Although a vast amount of preclinical evidence indicates the success of cell-based therapies for myocardial injuries, the underlying mechanisms involved in the repair/ regeneration achieved still need to be unraveled for all cell types used. ${ }^{113}$ Although a matter of great controversy and debate in the field, it has been suggested that heart repair or regeneration achieved after injection of stem cells occurs mainly by paracrine mechanisms involving the secretion of trophic and antiapoptotic factors and anti-inflammatory cytokines. ${ }^{113-115}$

Cellular tracking is an important part of the investigation of stem cell-based therapies for myocardial regeneration after either in situ or systemic injection of stem cells. Systemically delivered cells, or their products, must reach the heart in order to interact with the injury site and promote recovery; whereas those injected into the infarcted heart must remain in situ in order to promote recovery. ${ }^{110,116}$ In this case, intramyocardial injection seems to be more efficient than intracoronary injection. The decision between organ and systemic cellular delivery is one of the earliest to be made in cell-based therapies, and cellular-tracking methods are very helpful to this end.

It seems to be well established that stem cells applied systemically for therapies aiming toward cardiac repair are not found in the organ soon after injection, although the cells themselves were successfully labeled. ${ }^{117,118}$ Using a murine model of Chagas disease, we performed experiments that supported these findings. We injected SPION- and fluorescent nanoparticle-labeled mesenchymal cells into the tail vein of chagasic mice, and after 48 hours, only a very low number of fluorescent-labeled cells could be detected in the hearts by ex vivo imaging, using an in vivo imaging system and by confocal microscopy of tissue sections. In this model, we were not able to observe SPION-labeled cells in the heart by MRI, despite very efficient in vitro cellular labeling before injection ${ }^{119}$ as shown in Figure 1. This is consistent with another report, where the authors obtained only a limited visualization of SPION-labeled mesenchymal cells by MRI in dogs submitted to myocardial infarction, although radionuclide-labeled cells were detected by single photon emission computed tomography (SPECT)/computed tomography $(\mathrm{CT}){ }^{117}$

The injected cells can be more easily detected after intracoronary or intramuscular injection. In a porcine model, after 
injection into the myocardium of different concentrations of mesenchymal stem cells, labeled with iron fluorophore particles, it was possible to detect $10^{5}$ cells in the heart by MRI, although lower cell numbers were not detectable. ${ }^{120}$ In another study, the authors were able to follow SPION-labeled bone marrow progenitor cells by MRI in heart tissue for weeks after intracoronary injection, but a very large number $\left(13 \times 10^{6}\right)$ of cells were used in this study. ${ }^{121}$ Also using a very large number $\left(100 \times 10^{6}\right)$ of SPION-labeled mesenchymal stem cells delivered by intrapericardial administration in porcine models, the authors identified a significant number of cells retained in the cardiac tissue a few days after injection. ${ }^{122}$ In small rodents, it was possible to observe SPION-labeled mesenchymal stem cells (Endorem) after direct injection into the myocardial infarction scar. ${ }^{123}$ In our experiments, we also were able to detect SPION-labeled mesenchymal cells after injection of $3 \times 10^{6}$ cells into leg muscle of mice, ${ }^{15,24}$ $1 \times 10^{6}$ cells into rat striatum, ${ }^{124}$ and $5 \times 10^{6}$ rat intravitreally. ${ }^{63}$ In addition, using mononuclear cells from bone marrow, we detected SPION-labeled cells after the injection of $10^{6}$ cells into spinal cord ${ }^{62}$ and $5 \times 10^{6}$ cells intravitreally. ${ }^{63}$

As mentioned above, we could detect cells labeled with fluorescent nanoparticles by in vivo imaging better than cells labeled with SPIONs by MRI in chagasic mouse hearts after systemic injection. However, despite the higher sensitivity of the fluorescence-based imaging technique compared to MRI, it is not clinically translatable and has poor spatial resolution and limited penetration depth. In our study, we had to externalize the organs, including the heart, to acquire ex vivo images, otherwise the deep tissues could not be monitored. ${ }^{119,125}$ Brasil et al's unpublished results (2016) revealed that cardiomyocytes derived from mouse embryonic stem cells labeled with SPIONs, when directly injected into the heart muscle of chagasic mice, are detected by MRI 48 hours after injection. Furthermore, technetium-99m ( $\left.{ }^{99 \mathrm{~m}} \mathrm{Tc}\right)$-labeled bone marrow-derived mononuclear cells delivered by intracoronary injection in chronic chagasic patients are detected in the heart 24 hours after injection. ${ }^{126}$ These data suggest that labeled cells injected in situ can be detected by different in vivo imaging modalities at least within hours of cell injection.

Recently, Martens et al evaluated the biodistribution of pluripotent stem cells after intramyocardial injection in infarcted mice, by in vivo bioluminescence analysis. The authors could reveal and quantify massive early stem cell loss in heart and accumulation of them in the lung. When they increased the cell concentration, much larger numbers of cells were counted in the heart, although pulmonary accumulation still persisted. ${ }^{127}$ In our studies with chagasic mice injected systemically with mesenchymal cells, we also observed a preferential migration to the lung, liver, and spleen, but with a beneficial cardiac effect as well. ${ }^{19,125}$ In another study, investigating a canine model of myocardial infarction and a combination of SPECT/CT imaging for mesenchymal-cell tracking, a redistribution of labeled cells within 24-48 hours after intravenous injection, from the initial localization in the lungs to other nontarget organs such as liver, kidney, and spleen ${ }^{117}$ was detected. The functional recovery induced in stem cell-transplanted animals with heart lesions points to the still-incipient knowledge of the mechanisms of stem cell-mediated cardiac repair. ${ }^{118,125}$ Barbash et al ${ }^{118}$ showed, by ${ }^{99 m}$ Tc labeling, that mesenchymal stem cells injected into the left ventricular cavity could be detected in the heart in much greater quantities than when systemically administered. As mentioned above, intracoronary transplantation of mononuclear cells previously labeled with ${ }^{99 \mathrm{~m}} \mathrm{Tc}$ in chagasic patients showed a very low intensity of radioactivity $(2.3 \%)$ in the heart compared with other nontarget organs, such as the liver and the spleen, 24 hours after cell injection. ${ }^{126}$

Overall, regardless of the labeling and imaging modality used, cells are not found in significant numbers in the heart after systemic injection. Stem cells injected directly into the heart are more prone to be found in the organ, but some authors have found a substantial redistribution with time. Thus, it has been suggested that tissue-engineering techniques, utilizing scaffolds and cells, should be used for stem cell transplantation in order to improve cardiac retention and limit cell redistribution. ${ }^{127}$

In addition to allowing cell monitoring by MRI, SPIONs may potentially be directed in vivo to a target organ using magnets. Vandergriff et al labeled human cardiosphere-derived stem cells with ferumoxytol and heparin or protamine. They reported that the technique was not toxic to the cells. The authors performed an intracoronary injection of ferumoxytollabeled rat cardiosphere-derived stem cells in rats, with and without magnetic targeting. The authors reported that magnetic targeting improved cardiac homing of transplanted cells as assessed by fluorescence imaging, MRI, and quantitative polymerase chain reaction 24 hours after cell transplantation. ${ }^{128}$

Here, we present previously unpublished qualitative data on stem cell tracking in infarcted rats. We used immunostaining analysis by fluorescent or confocal microscopy to observe Feridex-labeled mesenchymal stem cells in a rat model of myocardial infarction. The animals were submitted to infarction by the ligation of the left anterior descending artery, and 24 hours later received an intramyocardial 
injection of $1 \times 10^{6}$ labeled stem cells in the left ventricle wall. Hearts were then harvested, 24 hours or 12 days after cell transplantation. We used an anti-dextran antibody to reveal the Feridex nanoparticles. Twenty-four hours after transplantation, it was possible to observe cells close to the injection site, which was near the infarcted area, as shown in Figure 3. The representative images shown in Figure 3 demonstrate a substantial number of transplanted cells at the injection site and in areas distant from the initial injection, as in the myocardial septum, evidencing relatively rapid cell redistribution in the heart. Figure 4 shows two dextranpositive cells 12 days after transplantation, illustrating the intense cell loss as mentioned above.

We also performed some pilot experiments examining proliferation and apoptosis in the cell-treated infarcted hearts. Figures 5 and 6 show an evaluation of proliferation (using an anti-Ki-67 antibody) and apoptosis (anti-activated caspase-3), respectively, in infarcted heart tissue treated with labeled cells. We found a few dextran-positive cells that were also positive for Ki-67 (Figure 5B-5B"'), suggesting that mesenchymal stem cells are still able to proliferate in vivo after transplantation and SPION labeling. The vast majority of proliferating cells are not dextran-positive (Figure $5 \mathrm{~A}-5 \mathrm{~A}^{\prime \prime \prime}$ ), and may be fibroblasts in the infarcted area. We also evaluated cells expressing activated caspase-3 after transplantation (Figure 6). Apoptotic cells could be detected in the tissue, as expected due to the injury. However, we found a very small number of dextran-positive cells close to the activated caspase-3 staining, suggesting that the apoptotic process of these cells is not intense in the first 24 hours after cell injection. As we did not perform evaluations after this time point, it is impossible to determine whether the disappearance of these cells from the heart can be attributed to apoptosis of the injected cells or to their redistribution. This question should be thoroughly investigated because adaptations of cell therapy must be governed by the intensity of each of these processes.

\section{Use of reporter genes}

In addition to direct labeling with SPIONs, different groups have used reporter gene methods to track cells with
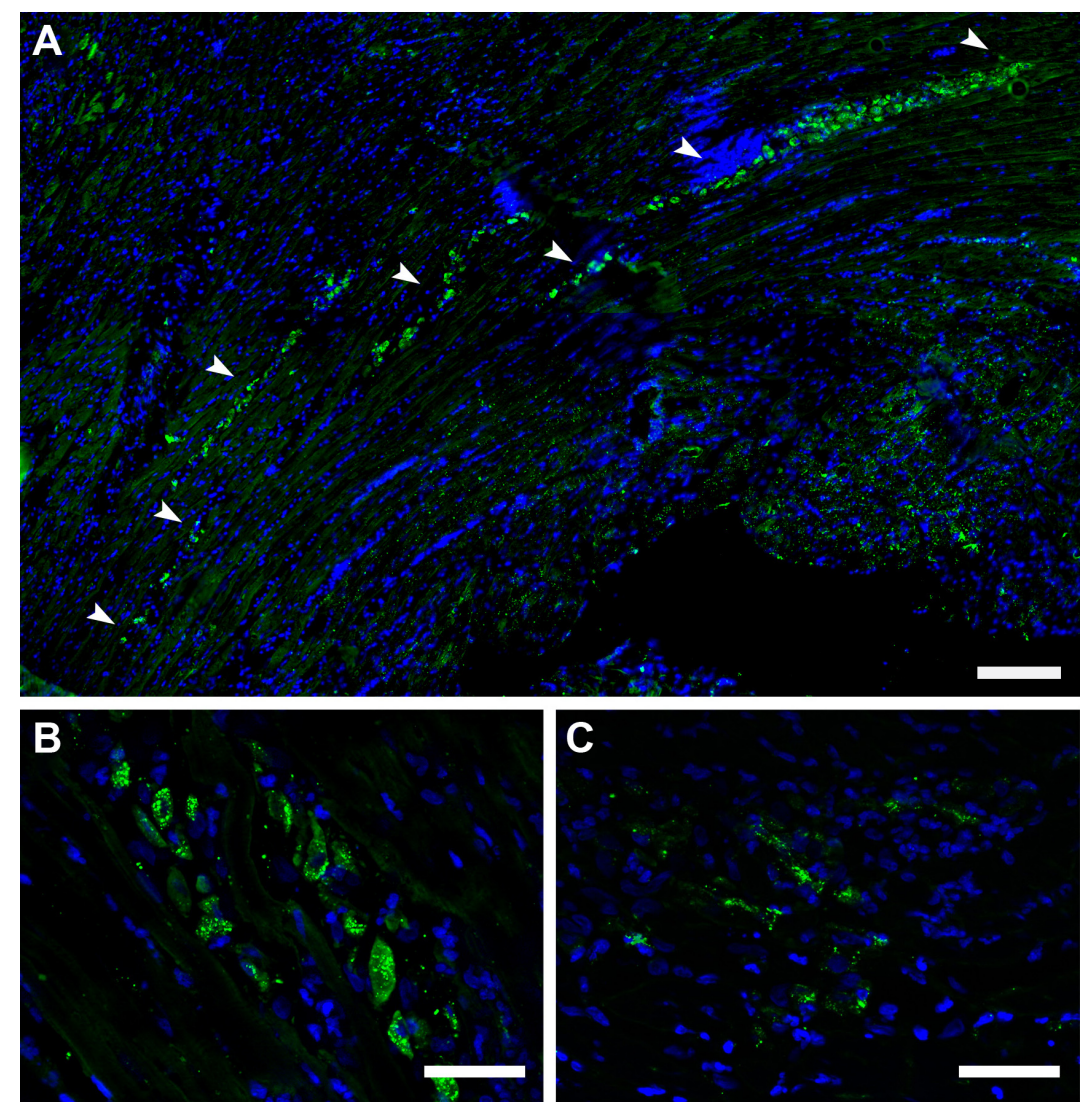

Figure 3 Tracking-labeled mesenchymal stem cells 24 hours after transplantation in infarcted hearts.

Notes: Positive cells for dextran (green) were found both at the injection site and distant (myocardial septum) from the injection site. The nuclei were counterstained with 4',6-diamidino-2-phenylindole (blue). (A) Photomontage showing cells in the injected area in the left ventricle wall (the arrowheads point for dextran-positive cells into the heart tissue). (B) Representative image of dextran-positive cells found in areas close to the injection site. (C) Representative image of labeled cells in a region far from the injection area, the myocardial septum. Scale bar $=200 \mu \mathrm{m}$ in (A) and $50 \mu \mathrm{m}$ in (B) and (C). 

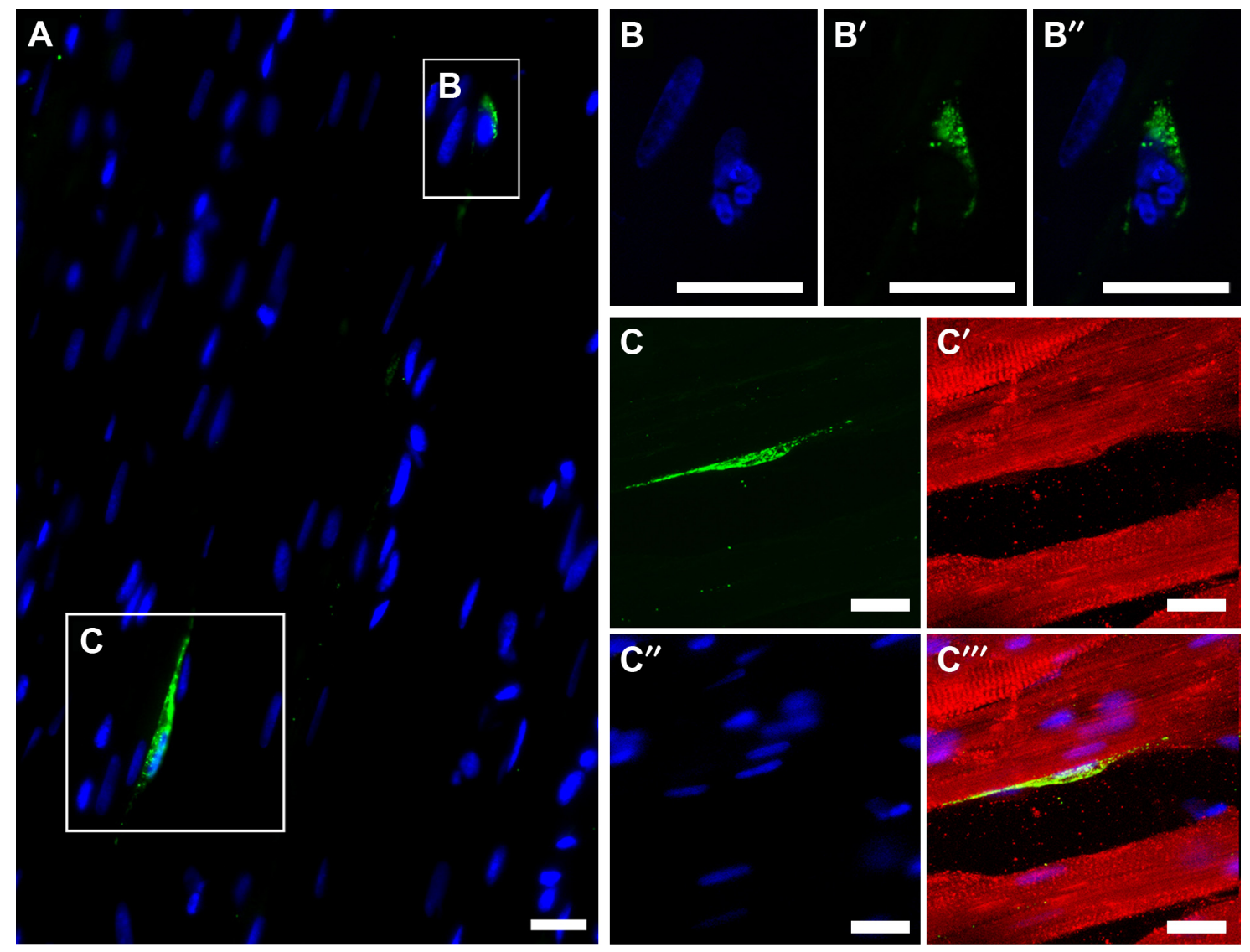

Figure 4 Tracking of transplanted labeled mesenchymal stem cells 12 days after transplantation in the infarcted heart.

Notes: Confocal microscopy of the tissue, showing rare positive cells for dextran (green) and nuclei counterstained with DAPI (blue). (A) Cells stained with dextran, showing different morphologies. (B-B") Higher magnification of the box in (A), showing (B) nuclei counterstained with DAPI, (B') dextran-positive cell, and (B') merged image.

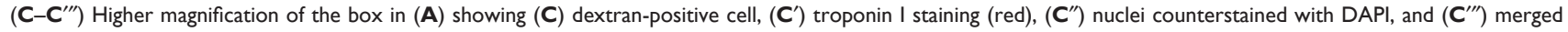
image. Scale bar $=50 \mu \mathrm{m}$.

Abbreviation: DAPI, 4',6-diamidino-2-phenylindole.

MRI. ${ }^{129}$ Campan et al used human ferritin heavy chain $(\mathrm{hFTH})$ as a reporter gene to track stem cells in vivo. They performed the transduction of porcine cardiospheres with a lentiviral vector to achieve overexpression of hFTH. After 45 minutes of myocardial infarction, rats received an intramyocardial infusion of nontransduced cardiospheres, hFTH-cardiospheres, or saline solution in the lesion border. The authors reported that the signal could be detected 1 week after cell transplantation, and that no significant change in its size was noted after 4 weeks. Also, the transduction did not alter the therapeutic potential of the cells, and both treated groups had a similar reduction in infarct size and improved left ventricular function compared with controls. Histologic analysis also indicated that ferritin overexpression did not affect cell differentiation. ${ }^{130}$

Chung et al used a reporter gene designed to express the antigens hemagglutinin A and myc on the surface of embryonic stem cells. ${ }^{131}$ Then, they conjugated SPIONs with monoclonal antibodies against the antigens. After myocardial infarction, the mice received an intramyocardial injection of the embryonic stem cells transduced with the reporter gene. Next, SPIONs conjugated with monoclonal antibodies were injected intravenously at 3, 5, 7, 10, and 14 days after cell transplantation. The authors reported that on day 3 , none of the animals had a signal in MRI, whereas the proportion increased to $50 \%, 75 \%$, and $100 \%$ on days 5,7 , and 10 , respectively.

\section{Conclusion and considerations}

The ideal nanoparticle for noninvasive cellular tracking must be biocompatible, nontoxic, and stable at neutral $\mathrm{pH}$ and physiological salinity. Specifically, for MRI tracking, the high magnetization of the nanoparticle is an important feature because it is a low-sensitivity technique. A combination of different molecular imaging modalities, reporter systems, and probes also can resolve some limitations of each tracking technique that is available at present.

Taking everything into consideration, SPIONs appear to be a promising technology to investigate homing, biodistribution, and fate of the injected cells used in therapies in preclinical and clinical studies. Although the available 

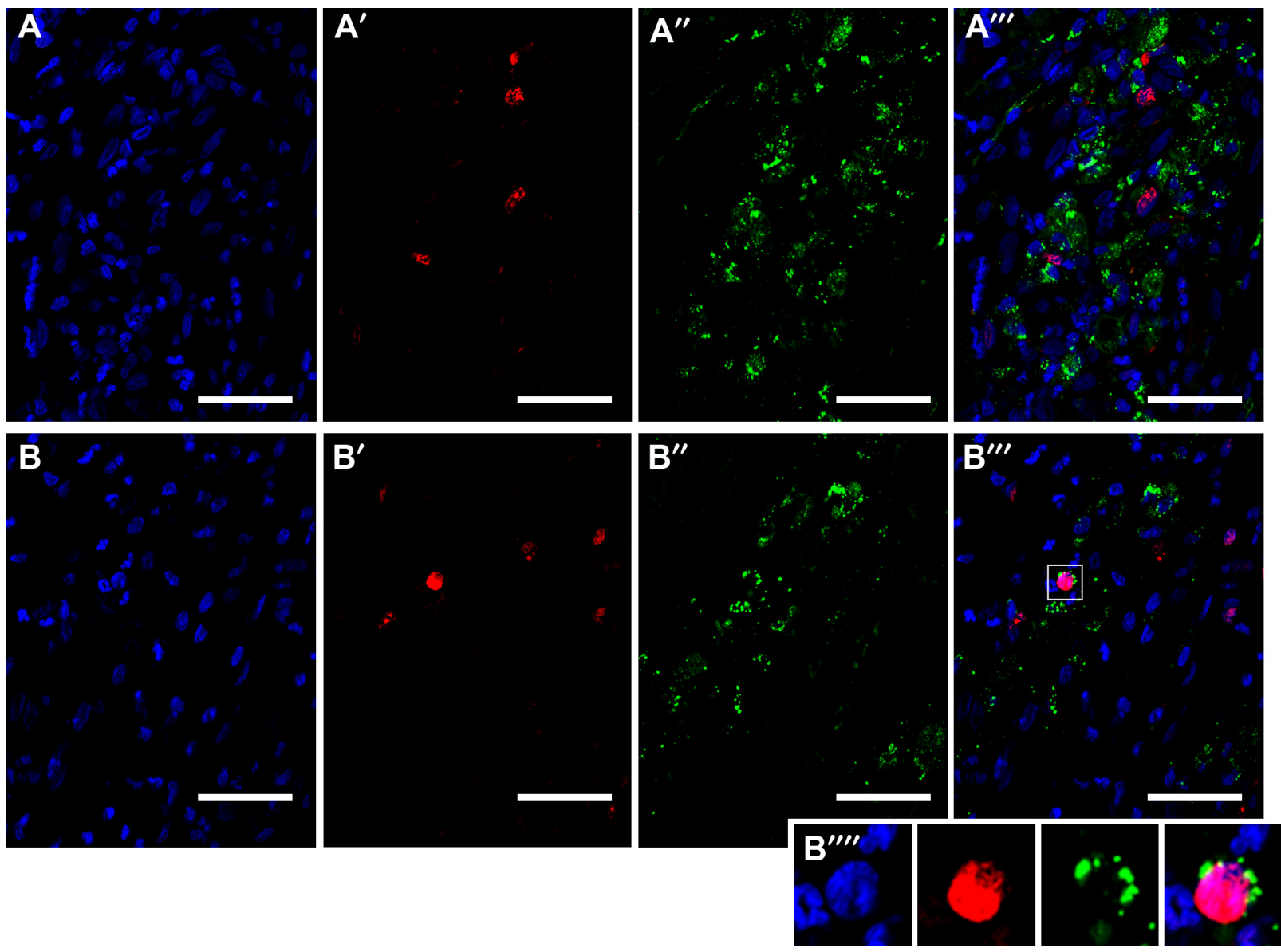

Figure 5 Qualitative analysis of proliferation in infarcted myocardium 48 hours after injury and 24 hours after Feridex-labeled mesenchymal cell transplantation.

Notes: Fluorescence microscopy images showing Ki-67-positive cells (red) and dextran-positive cells (green) in an area close to the injection site. The nuclei were

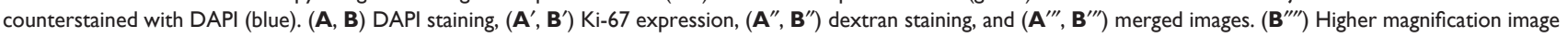
of the area is indicated by the white box showing a cell positive for both $\mathrm{Ki}-67$ and dextran. Scale bar $=50 \mu \mathrm{m}$.

Abbreviation: DAPI, 4',6-diamidino-2-phenylindole.
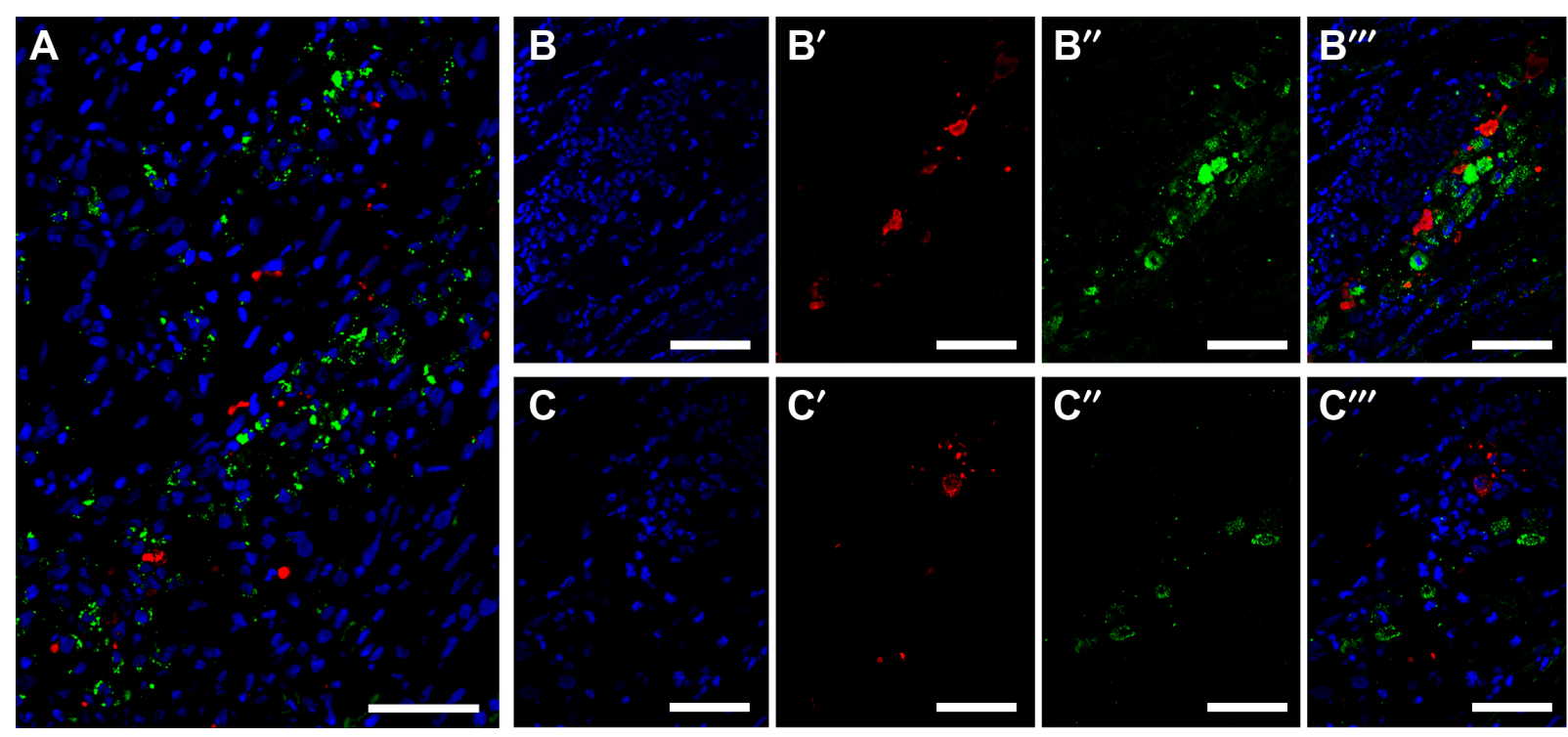

Figure 6 Qualitative analysis of apoptosis in infarcted heart region 48 hours after injury and 24 hours after cell transplantation.

Notes: Fluorescence microscopy images showing activated caspase-3-positive cells (red), dextran-positive cells (green), and nuclei counterstained with DAPI (blue). (A) Representative image close to the region of cell injection. (B-C') Images in higher magnification are also close to the injection site. (B, C) DAPI staining, (B', $\left.\mathbf{C}^{\prime}\right)$

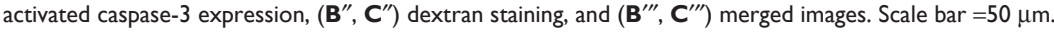

Abbreviation: DAPI, 4',6-diamidino-2-phenylindole. 
data indicate that SPIONs are safe, further studies on their long-term in vivo effects are still needed. To reduce safety concerns, labeling only a small percentage of the injected cells should be pursued. For MRI, this will require determination of the minimal number of cells detectable by this imaging technique, according to the cell type, disease, and administration route used in therapy.

\section{Acknowledgments}

This study was supported by grants from the Conselho Nacional de Desenvolvimento Científico e Tecnológico (CNPq), Coordenação de Aperfeiçoamento de Pessoal de Nível Superior (CAPES), and Fundação de Amparo à Pesquisa do Estado do Rio de Janeiro (FAPERJ). The authors wish to thank Janet W. Reid from JWR Associates, USA for revising and editing the language in the text.

\section{Disclosure}

The authors report no conflicts of interest in this work.

\section{References}

1. de Sa Silva F, Almeida PN, Rettore JV, et al. Toward personalized cell therapies by using stem cells: seven relevant topics for safety and success in stem cell therapy. J Biomed Biotechnol. 2012;2012:758102.

2. Liang X, Ding Y, Zhang Y, Tse HF, Lian Q. Paracrine mechanisms of mesenchymal stem cell-based therapy: current status and perspectives. Cell Transplant. 2014;23(9):1045-1059.

3. Wang J, Liao L, Tan J. Mesenchymal-stem-cell-based experimental and clinical trials: current status and open questions. Expert Opin Biol Ther. 2011;11(7):893-909.

4. Lai RC, Chen TS, Lim SK. Mesenchymal stem cell exosome: a novel stem cell-based therapy for cardiovascular disease. Regen Med. 2011;6(4):481-492.

5. Kim SJ, Lewis B, Steiner MS, Bissa UV, Dose C, Frank JA. Superparamagnetic iron oxide nanoparticles for direct labeling of stem cells and in vivo MRI tracking. Contrast Media Mol Imaging. 2016;11(1): $55-64$.

6. Tong L, Zhao M, Zhu S, Chen J. Synthesis and application of superparamagnetic iron oxide nanoparticles in targeted therapy and imaging of cancer. Front Med. 2011;5(4):379-387.

7. Villa C, Erratico S, Razini P, et al. Stem cell tracking by nanotechnologies. Int J Mol Sci. 2010;11(3):1070-1081.

8. Bianco P, Cao X, Frenette PS, et al. The meaning, the sense and the significance: translating the science of mesenchymal stem cells into medicine. Nat Med. 2013;19(1):35-42.

9. Kircher MF, Gambhir SS, Grimm J. Noninvasive cell-tracking methods. Nat Rev Clin Oncol. 2011;8(11):677-688.

10. Modo M, Cash D, Mellodew K, et al. Tracking transplanted stem cell migration using bifunctional, contrast agent-enhanced, magnetic resonance imaging. NeuroImage. 2002;17(2):803-811.

11. Dodd SJ, Williams M, Suhan JP, Williams DS, Koretsky AP, Ho C. Detection of single mammalian cells by high-resolution magnetic resonance imaging. Biophys J. 1999;76(1 Pt 1):103-109.

12. Jendelova $P$, Herynek V, Urdzikova L, et al. Magnetic resonance tracking of transplanted bone marrow and embryonic stem cells labeled by iron oxide nanoparticles in rat brain and spinal cord. J Neurosci Res. 2004; 76(2):232-243.

13. Shapiro EM, Skrtic S, Sharer K, Hill JM, Dunbar CE, Koretsky AP. MRI detection of single particles for cellular imaging. Proc Natl Acad Sci U S A. 2004;101(30):10901-10906.
14. Farrell E, Wielopolski P, Pavljasevic P, et al. Effects of iron oxide incorporation for long term cell tracking on MSC differentiation in vitro and in vivo. Biochem Biophys Res Commun. 2008;369(4):1076-1081.

15. Jasmin, Torres AL, Nunes HM, et al. Optimized labeling of bone marrow mesenchymal cells with superparamagnetic iron oxide nanoparticles and in vivo visualization by magnetic resonance imaging. $J$ Nanobiotechnology. 2011;9(1):4.

16. Guzman R, Uchida N, Bliss TM, et al. Long-term monitoring of transplanted human neural stem cells in developmental and pathological contexts with MRI. Proc Natl Acad Sci U S A. 2007;104(24): 10211-10216.

17. Lewin M, Carlesso N, Tung CH, et al. Tat peptide-derivatized magnetic nanoparticles allow in vivo tracking and recovery of progenitor cells. Nat Biotechnol. 2000;18(4):410-414.

18. Dodd $\mathrm{CH}, \mathrm{Hsu} \mathrm{HC}, \mathrm{Chu} \mathrm{WJ}$, et al. Normal T-cell response and in vivo magnetic resonance imaging of T cells loaded with HIV transactivatorpeptide-derived superparamagnetic nanoparticles. J Immunol Methods. 2001;256(1-2):89-105.

19. Ahrens ET, Feili-Hariri M, Xu H, Genove G, Morel PA. Receptormediated endocytosis of iron-oxide particles provides efficient labeling of dendritic cells for in vivo MR imaging. Magn Reson Med. 2003;49(6): $1006-1013$

20. Grimm J, Kircher MF, Weissleder R. [Cell tracking. Principles and applications]. Der Radiologe. 2007;47(1):25-33.

21. Hong H, Yang Y, Zhang Y, Cai W. Non-invasive cell tracking in cancer and cancer therapy. Curr Top Med Chem. 2010;10(12):1237-1248.

22. Naumova AV, Modo M, Moore A, Murry CE, Frank JA. Clinical imaging in regenerative medicine. Nat Biotechnol. 2014;32(8):804-818.

23. Youn $\mathrm{H}$, Hong KJ. In vivo non invasive molecular imaging for immune cell tracking in small animals. Immune Netw. 2012;12(6):223-229.

24. Jasmin, Torres AL, Jelicks L, de Carvalho AC, Spray DC, Mendez-Otero R. Labeling stem cells with superparamagnetic iron oxide nanoparticles: analysis of the labeling efficacy by microscopy and magnetic resonance imaging. Methods Mol Biol. 2012;906:239-252.

25. Marks KM, Nolan GP. Chemical labeling strategies for cell biology. Nat Methods. 2006;3(8):591-596.

26. Progatzky F, Dallman MJ, Lo Celso C. From seeing to believing: labelling strategies for in vivo cell-tracking experiments. Interface Focus. 2013;3(3):20130001.

27. Gilad AA, McMahon MT, Walczak P, et al. Artificial reporter gene providing MRI contrast based on proton exchange. Nat Biotechnol. 2007; 25(2):217-219.

28. Genove G, DeMarco U, Xu H, Goins WF, Ahrens ET. A new transgene reporter for in vivo magnetic resonance imaging. Nat Med. 2005; 11(4):450-454.

29. De Vocht N, Bergwerf I, Vanhoutte G, et al. Labeling of Luciferase/ eGFP-expressing bone marrow-derived stromal cells with fluorescent micron-sized iron oxide particles improves quantitative and qualitative multimodal imaging of cellular grafts in vivo. Mol Imaging Biol. 2011;13(6):1133-1145.

30. Goethals LR, Bos TJ, Baeyens L, De Geeter F, Devoogdt N, Lahoutte T. Camelid reporter gene imaging: a generic method for in vivo cell tracking. EJNMMI Res. 2014;4:32.

31. Gavins FN, Smith HK. Cell tracking technologies for acute ischemic brain injury. J Cereb Blood Flow Metab. 2015;35(7):1090-1099.

32. Diana V, Libani IV, Armentero MT, et al. A reliable indirect cell-labelling protocol for optical imaging allows ex vivo visualisation of mesenchymal stem cells after transplantation. Arch Ital Biol. 2013;151(3):114-125.

33. Weissleder R, Mahmood U. Molecular imaging. Radiology. 2001;219(2): 316-333.

34. James ML, Gambhir SS. A molecular imaging primer: modalities, imaging agents, and applications. Physiol Rev. 2012;92(2):897-965.

35. Chen ZY, Wang YX, Lin Y, et al. Advance of molecular imaging technology and targeted imaging agent in imaging and therapy. Biomed Res Int. 2014;2014:819324.

36. Zhang WY, Ebert AD, Narula J, Wu JC. Imaging cardiac stem cell therapy: translations to human clinical studies. J Cardiovasc Transl Res. 2011; 4(4):514-522. 
37. Bulte JW, Kraitchman DL. Iron oxide MR contrast agents for molecular and cellular imaging. NMR Biomed. 2004;17(7):484-499.

38. Santoyo Salazar J, Perez L, de Abril O, et al. Magnetic iron oxide nanoparticles in 10-40 nm range: composition in terms of magnetite/ maghemite ratio and effect on the magnetic properties. Chem Mater. 2011;23(6):1379-1386.

39. Lindemann A, Ludtke-Buzug K, Fraderich BM, Grafe K, Pries R, Wollenberg B. Biological impact of superparamagnetic iron oxide nanoparticles for magnetic particle imaging of head and neck cancer cells. Int J Nanomed. 2014;9:5025-5040.

40. Kodama RH. Magnetic nanoparticles. J Magnetism Magn Mater. 1999;200(1-3):359-372.

41. Mahmoudi M, Sant S, Wang B, Laurent S, Sen T. Superparamagnetic iron oxide nanoparticles (SPIONs): development, surface modification and applications in chemotherapy. Adv Drug Deliv Rev. 2011;63(1-2):24 46.

42. Néel L. Théorie Du Traînage Magnétique Des Ferromagnétiques En Grains Fins Avec Application Aux Terres Cuites [Theory of magnetic relaxation of ferromagnetism in fine grains with application to minerals] Annales de géophysique. 1949;5:99-136. French.

43. Gittleman JI, Abeles B, Bozowski S. Superparamagnetism and relaxation effects in granular $\mathrm{Ni}-\mathrm{SiO} 2$ and $\mathrm{Ni}-\mathrm{Al} 2 \mathrm{O} 3$ Films. Phys Rev $B$. 1974;9(9):3891-3897.

44. Kaiser R, Miskolczy G. Some applications of ferrofluid magnetic colloids. IEEE Trans Magn. 1970;6(3):694-698.

45. Massart R. Preparation of aqueous magnetic liquids in alkaline and acidic media. IEEE Trans Magn. 1981;17(2):1247-1248.

46. Tari A, Chantrell RW, Charles SW, Popplewell J. The magnetic properties and stability of a ferrofluid containing Fe3O4 particles. Physica B+C. 1979;97(1):57-64.

47. Sugimoto T, Matijević E. Formation of uniform spherical magnetite particles by crystallization from ferrous hydroxide gels. $J$ Colloid Interface Sci. 1980;74(1):227-243.

48. Stanicki D, Elst LV, Muller RN, Laurent S. Synthesis and processing of magnetic nanoparticles. Curr Opin Chem Eng. 2015;8:7-14.

49. Ocaña M, Rodriguez-Clemente R, Serna CJ. Uniform colloidal particles in solution: formation mechanisms. Adv Mater. 1995;7(2):212-216.

50. Sen T, Magdassi S, Nizri G, Bruce IJ. Dispersion of magnetic nanoparticles in suspension. Micro Nano Lett. 2006;1(1):39-42.

51. Mahmoudi M, Simchi A, Imani M, Milani AS, Stroeve P. Optimal design and characterization of superparamagnetic iron oxide nanoparticles coated with polyvinyl alcohol for targeted delivery and imaging. J Phys Chem B. 2008;112(46):14470-14481.

52. Jarrett BR, Frendo M, Vogan J, Louie AY. Size-controlled synthesis of dextran sulfate coated iron oxide nanoparticles for magnetic resonance imaging. Nanotechnology. 2007;18(3):035603.

53. Meincke M, Schlorf T, Kossel E, Jansen O, Glueer CC, Mentlein R. Iron oxide-loaded liposomes for MR imaging. Front Biosci. 2008;13: 4002-4008.

54. Sun C, Veiseh O, Gunn J, et al. In vivo MRI detection of gliomas by chlorotoxin-conjugated superparamagnetic nanoprobes. Small.2008;4(3): 372-379.

55. Lee H, Yu MK, Park S, et al. Thermally cross-linked superparamagnetic iron oxide nanoparticles: synthesis and application as a dual imaging probe for cancer in vivo. J Am Chem Soc. 2007;129(42):12739-12745.

56. Wang Y, Xu C, Ow H. Commercial nanoparticles for stem cell labeling and tracking. Theranostics. 2013;3(8):544-560.

57. Wang YX. Superparamagnetic iron oxide based MRI contrast agents: Current status of clinical application. Quant Imaging Med Surg. 2011;1(1):35-40.

58. Lu M, Cohen MH, Rieves D, Pazdur R. FDA report: Ferumoxytol for intravenous iron therapy in adult patients with chronic kidney disease. Am J Hematol. 2010;85(5):315-319.

59. Castaneda RT, Khurana A, Khan R, Daldrup-Link HE. Labeling stem cells with ferumoxytol, an FDA-approved iron oxide nanoparticle. J Vis Exp. 2011;(57):e3482.

60. Skelton RJ, Khoja S, Almeida S, et al. Magnetic resonance imaging of iron oxide-labeled human embryonic stem cell-derived cardiac progenitors. Stem Cells Transl Med. 2016;5(1):67-74.
61. Zaverucha-do-Valle C, Mesentier-Louro L, Gubert F, et al. Sustained effect of bone marrow mononuclear cell therapy in axonal regeneration in a model of optic nerve crush. Brain Res. 2014;1587:54-68.

62. Gubert F, Decotelli AB, Bonacossa-Pereira I, et al. Intraspinal bonemarrow cell therapy at pre- and symptomatic phases in a mouse model of amyotrophic lateral sclerosis. Stem Cell Res Ther. 2016;7:41.

63. Mesentier-Louro LA, Zaverucha-do-Valle C, da Silva-Junior AJ, et al. Distribution of mesenchymal stem cells and effects on neuronal survival and axon regeneration after optic nerve crush and cell therapy. PLoS One. 2014;9(10):e110722.

64. Ngen EJ, Wang L, Kato Y, et al. Imaging transplanted stem cells in real time using an MRI dual-contrast method. Sci Rep. 2015;5:13628.

65. Hoehn M, Kustermann E, Blunk J, et al. Monitoring of implanted stem cell migration in vivo: a highly resolved in vivo magnetic resonance imaging investigation of experimental stroke in rat. Proc Natl Acad Sci U S A. 2002;99(25):16267-16272.

66. Frank JA, Miller BR, Arbab AS, et al. Clinically applicable labeling of mammalian and stem cells by combining superparamagnetic iron oxides and transfection agents. Radiology. 2003;228(2):480-487.

67. Arbab AS, Yocum GT, Kalish H, et al. Efficient magnetic cell labeling with protamine sulfate complexed to ferumoxides for cellular MRI. Blood. 2004;104(4):1217-1223.

68. Qiu B, Xie D, Walczak P, et al. Magnetosonoporation: instant magnetic labeling of stem cells. Magn Reson Med. 2010;63(6):1437-1441.

69. Walczak P, Kedziorek DA, Gilad AA, Lin S, Bulte JW. Instant MR labeling of stem cells using magnetoelectroporation. Magn Reson Med. 2005;54(4):769-774.

70. Lei H, Nan X, Wang Z, et al. Stem cell labeling with superparamagnetic iron oxide nanoparticles using focused ultrasound and magnetic resonance imaging tracking. J Nanosci Nanotechnol. 2015;15(4): $2605-2612$.

71. Mathiasen AB, Hansen L, Friis T, Thomsen C, Bhakoo K, Kastrup J. Optimal labeling dose, labeling time, and magnetic resonance imaging detection limits of ultrasmall superparamagnetic iron-oxide nanoparticle labeled mesenchymal stromal cells. Stem Cells Int. 2013; 2013:353105

72. Bourzac CA, Koenig JB, Link KA, Nykamp SG, Koch TG. Evaluation of ultrasmall superparamagnetic iron oxide contrast agent labeling of equine cord blood and bone marrow mesenchymal stromal cells. Am J Vet Res. 2014;75(11):1010-1017.

73. Chen CC, Ku MC, D MJ, Lai JS, Hueng DY, Chang C. Simple SPION incubation as an efficient intracellular labeling method for tracking neural progenitor cells using MRI. PLoS One. 2013;8(2):e56125.

74. Bull E, Madani SY, Sheth R, Seifalian A, Green M, Seifalian AM. Stem cell tracking using iron oxide nanoparticles. Int J Nanomedicine. 2014;9:1641-1653.

75. Lee JH, Jung MJ, Hwang YH, et al. Heparin-coated superparamagnetic iron oxide for in vivo MR imaging of human MSCs. Biomaterials. 2012;33(19):4861-4871.

76. Barrow M, Taylor A, Nieves DJ, et al. Tailoring the surface charge of dextran-based polymer coated SPIONs for modulated stem cell uptake and MRI contrast. Biomater Sci. 2015;3(4):608-616.

77. Nishida K, Tanaka N, Nakanishi K, et al. Magnetic targeting of bone marrow stromal cells into spinal cord: through cerebrospinal fluid. Neuroreport. 2006;17(12):1269-1272.

78. Hamasaki T, Tanaka N, Kamei N, et al. Magnetically labeled neural progenitor cells, which are localized by magnetic force, promote axon growth in organotypic cocultures. Spine. 2007;32(21):2300-2305.

79. Cheng K, Shen D, Hensley MT, et al. Magnetic antibody-linked nanomatchmakers for therapeutic cell targeting. Nat Commun. 2014; 5:4880.

80. Ito A, Shinkai M, Honda H, Kobayashi T. Medical application of functionalized magnetic nanoparticles. J Biosci Bioeng. 2005; 100(1):1-11.

81. Cores J, Caranasos TG, Cheng K. Magnetically targeted stem cell delivery for regenerative medicine. J Funct Biomater. 2015;6(3):526-546.

82. Singh N, Jenkins GJ, Asadi R, Doak SH. Potential toxicity of superparamagnetic iron oxide nanoparticles (SPION). Nano Rev. 2010;1. 
83. Yildirimer L, Thanh NT, Loizidou M, Seifalian AM. Toxicology and clinical potential of nanoparticles. Nano Today. 2011;6(6):585-607.

84. Soenen SJ, Nuytten N, De Meyer SF, De Smedt SC, De Cuyper M. High intracellular iron oxide nanoparticle concentrations affect cellular cytoskeleton and focal adhesion kinase-mediated signaling. Small. 2010;6(7):832-842.

85. Jeng HA, Swanson J. Toxicity of metal oxide nanoparticles in mammalian cells. J Environ Sci Health A Tox Hazard Subst Environ Eng. 2006;41(12):2699-2711.

86. Hafeli UO, Riffle JS, Harris-Shekhawat L, et al. Cell uptake and in vitro toxicity of magnetic nanoparticles suitable for drug delivery. Mol Pharm. 2009;6(5):1417-1428.

87. Laurent S, Burtea C, Thirifays C, Hafeli UO, Mahmoudi M. Crucial ignored parameters on nanotoxicology: the importance of toxicity assay modifications and "cell vision". PLoS One. 2012;7(1):e29997.

88. Barhoumi L, Dewez D. Toxicity of superparamagnetic iron oxide nanoparticles on green alga Chlorella vulgaris. Biomed Res Int. 2013; 2013:647974.

89. Doak SH, Manshian B, Jenkins GJ, Singh N. In vitro genotoxicity testing strategy for nanomaterials and the adaptation of current OECD guidelines. Mutat Res. 2012;745(1-2):104-111.

90. Sharifi S, Daghighi S, Motazacker MM, et al. Superparamagnetic iron oxide nanoparticles alter expression of obesity and T2D-associated risk genes in human adipocytes. Sci Rep. 2013;3:2173.

91. Veranth JM, Kaser EG, Veranth MM, Koch M, Yost GS. Cytokine responses of human lung cells (BEAS-2B) treated with micron-sized and nanoparticles of metal oxides compared to soil dusts. Part Fibre Toxicol. 2007;4:2.

92. Nogueira de Melo AC, de Souza EP, Elias CG, et al. Detection of matrix metallopeptidase-9-like proteins in Trypanosoma cruzi. Exp Parasitol. 2010;125(3):256-263.

93. Mulens-Arias V, Rojas JM, Perez-Yague S, Morales MP, Barber DF. Polyethylenimine-coated SPIONs trigger macrophage activation through TLR-4 signaling and ROS production and modulate podosome dynamics. Biomaterials. 2015;52:494-506.

94. Arbab AS, Yocum GT, Rad AM, et al. Labeling of cells with ferumoxides-protamine sulfate complexes does not inhibit function or differentiation capacity of hematopoietic or mesenchymal stem cells. NMR Biomed. 2005;18(8):553-559.

95. Kostura L, Kraitchman DL, Mackay AM, Pittenger MF, Bulte JW. Feridex labeling of mesenchymal stem cells inhibits chondrogenesis but not adipogenesis or osteogenesis. NMR Biomed. 2004;17(7):513-517.

96. Zeng G, Wang G, Guan F, et al. Human amniotic membrane-derived mesenchymal stem cells labeled with superparamagnetic iron oxide nanoparticles: the effect on neuron-like differentiation in vitro. Mol Cell Biochem. 2011;357(1-2):331-341.

97. Chen YC, Hsiao JK, Liu HM, et al. The inhibitory effect of superparamagnetic iron oxide nanoparticle (Ferucarbotran) on osteogenic differentiation and its signaling mechanism in human mesenchymal stem cells. Toxicol Appl Pharmacol. 2010;245(2):272-279.

98. Balakumaran A, Pawelczyk E, Ren J, et al. Superparamagnetic iron oxide nanoparticles labeling of bone marrow stromal (mesenchymal) cells does not affect their "stemness". PLoS One. 2010;5(7):e11462.

99. Anzai Y, Piccoli CW, Outwater EK, et al. Evaluation of neck and body metastases to nodes with ferumoxtran 10-enhanced MR imaging: phase III safety and efficacy study. Radiology. 2003;228(3):777-788.

100. Thygesen K, Alpert JS, Jaffe AS, Simoons ML, Chaitman BR, White HD. Third universal definition of myocardial infarction. Nat Rev Cardiol. 2012;9(11):620-633.

101. Thygesen K, Alpert JS, White HD, et al. Universal definition of myocardial infarction. Circulation. 2007;116(22):2634-2653.

102. Hellermann JP, Jacobsen SJ, Gersh BJ, Rodeheffer RJ, Reeder GS, Roger VL. Heart failure after myocardial infarction: a review. Am J Med. 2002;113(4):324-330.

103. Ogawa $\mathrm{H}$, Suefuji $\mathrm{H}$, Soejima $\mathrm{H}$, et al. Increased blood vascular endothelial growth factor levels in patients with acute myocardial infarction. Cardiology. 2000;93(1-2):93-99.
104. Zhao T, Zhao W, Chen Y, Ahokas RA, Sun Y. Vascular endothelial growth factor (VEGF)-A: role on cardiac angiogenesis following myocardial infarction. Microvascu Res. 2010;80(2):188-194.

105. Meloni M, Caporali A, Graiani G, et al. Nerve growth factor promotes cardiac repair following myocardial infarction. Circ Res. 2010; 106(7):1275-1284.

106. Korf-Klingebiel M, Reboll MR, Klede S, et al. Myeloid-derived growth factor (C19orf10) mediates cardiac repair following myocardial infarction. Nat Med. 2015;21(2):140-149.

107. de Souza GT, Zanette Rde S, do Amaral DL, et al. Satellite cells: regenerative mechanisms and applicability in muscular dystrophy. Stem Cells Int. 2015;2015:487467.

108. Mahmoud AI, Kocabas F, Muralidhar SA, et al. Meis1 regulates postnatal cardiomyocyte cell cycle arrest. Nature. 2013;497(7448):249-253.

109. O'Neill TJ 4th, Mack CP, Taylor JM. Germline deletion of FAKrelated non-kinase delays post-natal cardiomyocyte mitotic arrest. J Mol Cell Cardiol. 2012;53(2):156-164.

110. Krishna KA, Krishna KS, Berrocal R, Rao KS, Sambasiva Rao KR. Myocardial infarction and stem cells. J Pharm Bioall Sci. 2011;3(2): 182-188.

111. Fisher SA, Zhang H, Doree C, Mathur A, Martin-Rendon E. Stem cell treatment for acute myocardial infarction. Cochrane Database Syst Rev. 2015;(9):CD006536.

112. Wang X, Zhang J, Zhang F, et al. The clinical status of stem cell therapy for ischemic cardiomyopathy. Stem Cell Int. 2015;2015:135023.

113. Wen Z, Zheng S, Zhou C, Wang J, Wang T. Repair mechanisms of bone marrow mesenchymal stem cells in myocardial infarction. J Cell Mol Med. 2011;15(5):1032-1043.

114. Hansson EM, Lindsay ME, Chien KR. Regeneration next: toward heart stem cell therapeutics. Cell Stem Cell. 2009;5(4):364-377.

115. Chen Y, Ye L, Zhong J, et al. The structural basis of functional improvement in response to human umbilical cord blood stem cell transplantation in hearts with postinfarct LV remodeling. Cell Transplant. 2015;24(6):971-983.

116. Forrester JS, Price MJ, Makkar RR. Stem cell repair of infarcted myocardium: an overview for clinicians. Circulation. 2003;108(9): 1139-1145.

117. Kraitchman DL, Tatsumi M, Gilson WD, et al. Dynamic imaging of allogeneic mesenchymal stem cells trafficking to myocardial infarction. Circulation. 2005;112(10):1451-1461.

118. Barbash IM, Chouraqui P, Baron J, et al. Systemic delivery of bone marrow-derived mesenchymal stem cells to the infarcted myocardium: feasibility, cell migration, and body distribution. Circulation. 2003;108(7):863-868.

119. Jasmin, Jelicks LA, Tanowitz HB, et al. Molecular imaging, biodistribution and efficacy of mesenchymal bone marrow cell therapy in a mouse model of Chagas disease. Microbes Infect. 2014;16(11):923-935.

120. Hill JM, Dick AJ, Raman VK, et al. Serial cardiac magnetic resonance imaging of injected mesenchymal stem cells. Circulation. 2003;108(8):1009-1014.

121. Graham JJ, Foltz WD, Vaags AK, et al. Long-term tracking of bone marrow progenitor cells following intracoronary injection postmyocardial infarction in swine using MRI. Am J Physiol Heart Circ Physiol. 2010;299(1):H125-H133.

122. Blazquez R, Sanchez-Margallo FM, Crisostomo V, et al. Intrapericardial administration of mesenchymal stem cells in a large animal model: a bio-distribution analysis. PLoS One. 2015;10(3):e0122377.

123. Amsalem Y, Mardor Y, Feinberg MS, et al. Iron-oxide labeling and outcome of transplanted mesenchymal stem cells in the infarcted myocardium. Circulation. 2007;116(Suppl 11):I38-I45.

124. Moraes L, Vasconcelos-dos-Santos A, Santana FC, et al. Neuroprotective effects and magnetic resonance imaging of mesenchymal stem cells labeled with SPION in a rat model of Huntington's disease. Stem Cell Res. 2012;9(2):143-155.

125. Jasmin, Jelicks LA, Koba W, et al. Mesenchymal bone marrow cell therapy in a mouse model of chagas disease. Where do the cells go? PLoS Negl Trop Dis. 2012;6(12):e1971. 
126. Barbosa da Fonseca LM, Xavier SS, Rosado de Castro PH, et al. Biodistribution of bone marrow mononuclear cells in chronic chagasic cardiomyopathy after intracoronary injection. Int J Cardiol. 2011; 149(3):310-314.

127. Martens A, Rojas SV, Baraki H, et al. Substantial early loss of induced pluripotent stem cells following transplantation in myocardial infarction. Artif Organs. 2014;38(11):978-984.

128. Vandergriff AC, Hensley TM, Henry ET, et al. Magnetic targeting of cardiosphere-derived stem cells with ferumoxytol nanoparticles for treating rats with myocardial infarction. Biomaterials. 2014;35(30): 8528-8539

129. Gilad AA, Winnard PT Jr, van Zijl PC, Bulte JW. Developing MR reporter genes: promises and pitfalls. NMR Biomed. 2007; 20(3):275-290.
130. Campan M, Lionetti V, Aquaro GD, et al. Ferritin as a reporter gene for in vivo tracking of stem cells by $1.5-\mathrm{T}$ cardiac MRI in a rat model of myocardial infarction. Am J Physiol Heart Circ Physiol. 2011; 300(6):H2238-H2250.

131. Chung J, Kee K, Barral JK, et al. In vivo molecular MRI of cell survival and teratoma formation following embryonic stem cell transplantation into the injured murine myocardium. Magn Reson Med. 2011;66(5):1374-1381.

132. Pauwels K, Gijsbers R, Toelen J, et al. State-of-the-art lentiviral vectors for research use: risk assessment and biosafety recommendations. Curr Gene Ther. 2009;9(6):459-474.
International Journal of Nanomedicine

\section{Publish your work in this journal}

The International Journal of Nanomedicine is an international, peerreviewed journal focusing on the application of nanotechnology in diagnostics, therapeutics, and drug delivery systems throughout the biomedical field. This journal is indexed on PubMed Central, MedLine, CAS, SciSearch ${ }^{\circledR}$, Current Contents ${ } /$ Clinical Medicine,

\section{Dovepress}

Journal Citation Reports/Science Edition, EMBase, Scopus and the Elsevier Bibliographic databases. The manuscript management system is completely online and includes a very quick and fair peer-review system, which is all easy to use. Visit http://www.dovepress.com/ testimonials.php to read real quotes from published authors.

Submit your manuscript here: http://www.dovepress.com/international-journal-of-nanomedicine-journal 